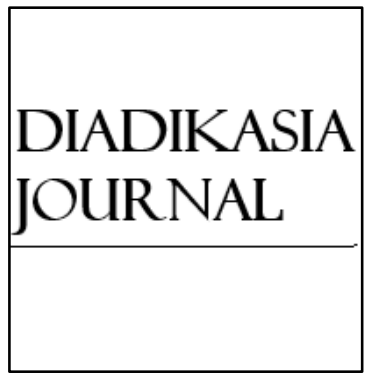

Diadikasia Journal

ISSN: $2721-9070$

Copyright $\odot 2020$ Diadikasia Organization

https://diadikasia.pubpub.org/

Volume 1(1): 24-38.

DOI: $10.21428 / 8 c 841009.1 a b a 57 e 2$

\title{
MODEL OF ISLAMIC GUIDANCE AND COUNSELING IN DEVELOPING RELIGIOUS BEHAVIOR AND INTEREST OF LEADING ISLAMIC RELIGIOUS FORMER RECIDIVIST IN PADEPOKAN MAUNG BODAS CIAMIS FOUNDATION
}

\author{
Rahman Abdullah \\ rahmanabdullahmuhtar@gmail.com \\ IAIN Syekh Nurjati \\ Jl. Perjuangan, Cirebon, Indonesia 45131
}

\begin{abstract}
A criminal can repent with the guidance of Allah SWT. The Padepokan Maung Bodas Ciamis Foundation has a concern to accommodate and guide ex-recidivists who want to repent. The problem in this research is how is the process of Islamic guidance and counseling in fostering religious behavior and interest in studying Islamic religion of former recidivists at the Padeopokan Maung Bodas Ciamis Foundation and How are the results of the guidance process. This research aims to find out how the process of Islamic guidance and counseling conducted in Padepokan Maung Bodas to former recidivists later to find out about the results of the existence of Islamic guidance and counseling. The research method used in this study is a qualitative approach; data collection in this study were observation, interviews, and documentation. Data analysis techniques include data reduction, data presentation, and conclusion drawing. The results of this study are guidance conducted on the former recidivist covering prayer therapy, then conducting routine weekly activities that are filled with joint prayer and learning essential worship and reading the Qur'an. Then after following the guidance, visible growth in religious behavior and interest in learning Islam from the former recidivists.
\end{abstract}

Keywords: Islamic guidance and counseling, Former recidivists, Religious behavior.

\section{Introduction}

Pressure and demands that continue to come and not fulfill the needs of a person's life will cause a problem in social life. If a person lacks awareness of the religious spirit and does not have righteous behavior and behavior taught by religion, a person will always tend to stay away from what religion teaches, which is good, so when faced with 
difficult situations, the person will take negative actions. High crime rates and violent criminal acts such as robbery, murder, theft, is one example of the dryness of one's soul that will be splashed with religious teachings and the absence of peace of soul in a person. Humans are equipped with potential as creatures who are always ordered to do good, but the more dominant contrary desires in a person will lead to deviations in the behavior of a person. Distortion of human behavior is a black record in human life. (Rajab, 2012) Therefore, growing a religious soul that will be reflected in the attitudes and behavior of life and presenting one's interest in learning Islam in a person is important, so humans can run their lives well and behave and behave positively in life.

Islamic guidance and counseling activities are one way to raise awareness of religious behavior or behavior that always breathes goodness and presents peace in the soul of someone who is experiencing pressure in life and against someone who has been involved in deviant or criminal behavior, one of them is a former criminal or recidivist. Guidance can be interpreted as an activity to guide or show and help others (Jamal Makmura, 2010). Counseling, according to Carl Rogers, quoted by Latipun (2011), believes counseling is a therapeutic relationship carried out by a counselor with a client who has a goal to make changes in the client's self. (Latipun, 2011)

According to Hussein Rasool in the Journal of Pastoral Care \& Counseling, Islamic counseling guidance is "Islamic counseling based on this clear outline of Islam; he evaluates the most common secular theories. While these include psychoanalysis and psychodynamic counseling, client-centered therapy, solution-focused brief therapy, and cognitive behavioral therapy, he also examines marital and addiction counseling. "(Rasool, 2016). Counseling generally has good intentions and is solutive for someone who is experiencing difficulties or experiencing problems. Therefore, counseling is useful in helping someone (client) so that someone knows his identity and position and has the desire and courage to do good and something useful in life. (Mubarok, 2000)

Therefore, Islamic guidance and counseling have an understanding as a process of guidance and counseling based on Islamic teachings, to help someone who is having problems in order to find solutions to their problems and achieve world and hereafter happiness. "(Sutoyo, 2017 ) One of the non-governmental organizations that have activities in conducting guidance to people who have fallen into the world of crime or former recidivists and wants to improve their behavior and want to repent is the Padepokan Maung Bodas Ciamis Foundation. The foundation is located in Cisema Village, Rancah Subdistrict, Ciamis Regency, the foundation is engaged in social activities that are accommodating and providing physical and spiritual guidance to former recidivists or people who have a dark past who want to emigrate from the dark world to a better world.

The guidance and guidance efforts of former recidivists at the Padepokan Maung Bodas Ciamis Foundation are to make the former recidivist a person who has selfconfidence and feels valued by others and can be useful in social life in his environment. At the foundation, ex-recidivists receive spiritual and physical guidance; that is, former 
criminals are taught the teachings of Islam. They are given advice or advice that can arouse religious souls and can have good religious attitudes and always have positive behavior. These activities expect that when activities like the above have guided the former recidivists, they will be accepted and useful in social life and not return to the world of crime-the former recidivist.

Please note that religious behavior can be interpreted as all activities or activities carried out by humans in their lives that are based on or have the values of religious beliefs they hold. I will start doing worship activities in their daily lives. In addition to the growth of religious behavior also the growing interest in studying religion in the former recidivist. Learning can be interpreted as a change in behavior or behavior in a better direction or vice versa through a process of practice and experience. Learning is a change that occurs within a person who states himself as a pattern, a new understanding of the attitudes, skills, habits, intelligence. (Purwanto, 2013) So, automatically someone who wants to change their life behavior becomes shaded by teaching religion, then he will have an interest in studying the teachings of his religion.

Maung Bodas Foundation in carrying out its activities fostering and guiding the former criminals to foster religious behavior and interest in learning the religion of Islam can be said to use the process of Islamic guidance and counseling because in practice the former criminals get the guidance, especially in knowing and learning the teachings of Islam which when they are still in the black world not practicing their religion well. In addition to guidance as above, former recidivists also get advice and enlightenment about the meaning of a good life and motivate them not to return to the criminal world and always be severe in living a new life that is to become someone better. Therefore guidance and counseling are essential in fostering former criminals back on the right path.

Therefore, from this background, the researcher is interested in bringing up a study entitled The Islamic Guidance and Counseling Model in Fostering Religious Behavior and Interest in Studying Islamic Religion Former Recidivist at Padepokan Maung Bodas Ciamis Foundation. It is hoped that the theme can inspire individual institutions or parties who have concern for people who have a dark past and want to repent and return to a good life, can imitate what the Maung Bodas Foundation has done in carrying out its activities.

\section{Methods}

Departing from the problems raised in this study, the author uses descriptive qualitative research methods. Qualitative research is research conducted to describe and analyze the events of an event, social activities, attitudes, behaviors, beliefs, understanding of people's thoughts both in groups and individually. Then in this study are descriptive or describe and explain what they are by the facts in the field of research and accordance with information obtained through observation activities, interviews, and 
documentation activities carried out by the author as a means of collecting data that has links with the research theme. (Rukajat, 2018)

The data sources of this study are divided into two data sources:

\section{A. Data Sources}

\section{Primary Data Sources}

Primary data sources and critical informants from this research are information or data obtained from the leaders of the padepokan, then the chairman of the foundation and the administrators, as well as students or pilgrims, fostered from the padepokan

\section{Secondary Data Sources}

Secondary data sources used in this study are in the form of books or written documents or written works that are related, and there is a significant relationship with research and can be used as supporting data in the study.

\section{B. Data Collection Techniques}

Proper research is the right to research the method of collecting data. Data collection techniques are an essential aspect of conducting research. Data collection techniques are carried out through interviews or interviews, observations or observations, and documentation or documentation. (Firdaus, 2018)

\section{Data Analysis Techniques}

In this research, data analysis techniques include data collection, data reduction, and then data presentation.

\section{Discussion}

\section{A. Profile of the Padepokan Maung Bodas Ciamis Foundation}

Padepokan Maung Bodas Foundation, located at Jl. Dadiharja 006/023 Cisema Rancah Village Rancah Subdistrict Ciamis Regency was initially formed from a small community that cares about social issues that were founded in 2009. In subsequent developments, Maung Bodas was established and officially registered at Kemenkumham as a social organization that cares about social problems, humanity, and religion on June 1, 2016. Since then, Maung Bodas has contributed to social-humanitarian and religious activities.

The philosophical meaning of the name "Maung Bodas" or in the Indonesian language means white tiger. The word Maung Bodas is an acronym from the phrase "Superior Human Siliwangi Blood Boga," which, when traced its meaning deeply that "Featured Man," here are people who join along with this Yayasan are people who have advantages. They can provide benefits in social life, then "Boga Siliwangi Blood" means to 
have principles as Siliwangi who has a philosophy of life, one after another, one after another, one another, one another, and one fragrance, which means can be a protector in this life. Departing from the name Maung Bodas is expected to be a prayer for anyone who joins the Padepokan Foundation Maung Bodas can become a superior human being who can provide benefits to many people and can be role models in this life.

The vision of the Padepokan Maung Bodas Foundation is to become an institution capable of creating and empowering the welfare of members and the community that bases itself on the values of nationalism and religiosity in the Republic of Indonesia Unitary Republic based on the Pancasila and the 1945 Constitution which is always sovereign, has a personality in the field of cultural and independent in the economic field. (ADART Padepokan Maung Bodas, 2016).

Tabel. 1. Profil Yayasan Maung Bodas

\begin{tabular}{lll}
\hline $\mathbf{1}$ & Nama Yayasan & Yayasan Maung Bodas \\
\hline $\mathbf{2}$ & SK. Kemenkumham RI & AHU-0014629.AH.01.04.Tahun 2016 \\
$\mathbf{3}$ & Alamat Kantor Pusat & Jl. Dadiharja 006/023 Cisema Desa Rancah Kecamatan \\
& & Rancah Kabupaten Ciamis 46387 \\
4 & No. Telepon & $082315794569 / 081234563969$ \\
$\mathbf{5}$ & Kegiatan & Keagamaan, Sosial, Kemanusiaan \\
$\mathbf{6}$ & Struktur Kepengurusan & Ketua Umum : Ujang Ano \\
& & Ketua Pembina : Tatang Hidayat \\
& & Sekretaris Umum : Agus Sopandi \\
& & Bendahara Umum: Dodi Daryanto, S. E \\
& Ketua Pengawas : Toto Suryanto \\
& Anggota Pengawas: Dedi Hidayat \\
7 & Pembimbing/Pengajar & 1. Uwa Ano Lodaya \\
& & 2. Ustadz Ruhimat Purnama \\
& & 3. Ustadz Mumu \\
$\mathbf{8}$ & Motto & 4. Ustadz Ajat \\
\hline
\end{tabular}

\section{B. The Situation of Guidance and Guidance Formation of Former Recidivists at the Padepokan Maung Bodas Ciamis Foundation}

The condition of the place and excellent facilities in a place will support the success of an activity that is held in that place. Based on observations of researchers in Padepokan Maung Bodas, which has an area of 2800 square meters, from the aspect of site conditions and facilities is sufficient for the holding of guidance activities for former recidivists or people who are marginalized in the community.

The place of Padung Maung Bodas consists of:

(1) A mosque building that has a classic architecture with building materials using wood and bamboo.

(2) The first two-level meeting building is the first level and the second two floors, the building is usually used for ex-recidivist guidance and coaching activities, such as 
weekly activities in the form of joint prayer and dhikr together and also used as a place for teaching and learning. This building is made of wood and bamboo.

(3) The secretariat building where special guests are received and the place of the chair of the foundation.

(4) A legit building or a place to store rice.

(5) Kitchen, as a place for cooking and preparing food for the guidance participants who stay overnight.

(6) There are four bathrooms in the entire building.

(7) The two-story saung building in front of the mosque.

(8) Warehouse building.

(9) In addition to the building above, in Padepokan, there are also animals that are kept in the foundation environment, namely one horse and one long-tailed monkey.

It should be noted that all buildings in the Padepokan Maung Bodas foundation use wood and bamboo materials that can provide natural and beautiful lighting, except for bathroom buildings that use cement and brick material. The location of this hermitage is in an area that has a contour of hilly land so that the place faces a valley that has a beautiful view. Even though they already have a place for mentoring former exrecidivists, the head of the foundation feels that the place they are doing activities is still considered to have shortcomings and limitations, especially in the facilities, whether it is a place of rest for rehabilitation patients that are applied or other facilities such as meeting the needs of life such as eating and drinking for patients who rely on the foundation's own business as well as donations or self-help from members of Maung Bodas itself.

\section{Former Recidivist Adviser at the Padepokan Maung Bodas Ciamis Foundation}

According to Wa Ano, there are about 15 administrators at this foundation. However, the researchers observed who were active in providing guidance and assistance as well as providing learning about the teachings of Islam; there were at least four mentors. The supervisors consisted of the chairman of the foundation itself, Ujang Ano or commonly called Wa Ano; then there were Ustad Ajat, Ustad Ruhimat and Ustad Mumu. With the few managers who are active in providing teaching and mentoring, it is felt by Wa Ano as one of the obstacles that the foundation has in providing services to guidance counsellors because sometimes patients who come and need guidance and rehabilitation exceed the capabilities of the existing management staff.

The supervisors and instructors at Padepokan Maung Bodas are someone who certainly has an understanding of ethical, religious teachings and has a high social life; such a thing must be possessed by a supervisor as a basic competency in carrying out Islamic guidance and counselling activities so that they can take guidance and formation of former bad people with sincerity and patience in guiding former criminals to the right path. (Sutoyo, 2017) 


\section{Guidance for Forming Recidivists in the Maung Bodas Ciamis Foundation}

Padepokan Maung Bodas Foundation in one of its activities is to provide guidance, assistance, guidance and even rehabilitation of people who have been involved in the world of crime or drug users. Mainly this foundation provides guidance to former criminals or recidivists who want to repent and improve their behaviour and attitudes in order to be better. Moreover, of course, doing all its activities based on or based on Islamic teachings. The guidance of the former criminal in Padepokan Maung Bodas was carried out by providing learning about the procedures of worship, then reading the Qur'an and other basic Islamic sciences.

\section{F. Source of Funds for Guidance Activities of Former Recidivists at Padepokan Maung Bodas Ciamis Foundation}

In carrying out coaching activities for ex-recidivists at the Padepokan Maung Bodas foundation, of course, there must be funds provided by the foundation in carrying out these activities, because coaching activities for ex-recidivists or people who need other guidance are free of charge in any activities that are followed by people -that person. Whether it is the weekly guidance participants or the guidance participants that are put in place are all free of charge. Whereas if you want to contribute to the foundation, the foundation will accept it and the voluntary contributions from the participants of the guidance.

\section{G. Islamic Guidance and Counseling Model in Growing Religious Behavior and Interest in Studying Islamic Religion Former Recidivist at Padepokan Maung Bodas Ciamis Foundation}

Guidance and assistance to former recidivists or former criminals at the Maung Bodas foundation is one of the many activities carried out by the Maung Bodas foundation which engages in religious, social and community activities. The Islamic-based guidance and counselling process at this foundation is carried out of course through methods or models that are considered to be of maximum use and impact. Ujang Ano or familiarly called Wa Ano as chairman of the foundation explained that someone who was about to be guided or fostered in Maung Bodas had to go through the ruqiyah stages, this was done to give calm to one's mind and be ready to undergo guidance at the foundation.

According to Wa Ano, ex-recidivists who have been in ruqiyah will see the conditions whether the person must be applied in the sense of getting intensive guidance from the foundation within a certain period of time, or only required to follow the routine weekly activities of the foundation which are held on Tuesday nights and Friday nights in the form of joint prayer activities and study and study of Islam. So if the former recidivist already has a keen awareness and determination to emigrate, the foundation will suggest to the term "outpatient" by taking part in routine activities organized by the foundation 
in the form of prayer therapy, dzikir therapy and Islamic religious learning for later a former recidivist which used to have a dark past and was far from the guidance of religion, will return to the nature of mankind that is always doing good and behaving according to the teachings of Islam. Therapeutic activities, such as dhikr and prayer services held at this foundation, have an essential position in the activities of Islamic guidance and counselling towards the former recidivist, as Carl Rogers said quoted by Latipun that counselling and counselling activities are therapeutic relationships carried out by a counsellor with a client who has a goal to make changes to the self of the client. (Latipun, 2011)

After getting ruqiyah and someone declared ready to undergo guidance and coaching activities, then then they are given therapies such as therapy through the media of dhikr, then dual therapy, then they are guided by religious activities such as dhikr together, tahlil, riyadloh, and studies that all these activities are expected to prevent the former criminals from returning the wrong path.

Activities in order to guide the former recidivists are carried out routinely every Tuesday night and Friday night. Activities carried out on Tuesday night is in the form of Koran reading activities or a necessity which is followed by guidance participants and by the general public, because this activity is carried out freely followed by anyone. Then the activity on Friday night was filled with prayer and dhikr activities together after the prayers continued with spiritual activities that were usually delivered by the administrators of the Maung Bodas foundation and continued with learning activities for the worshipers present and especially for former recidivists who were present and want to learn about Islam.

The material taught in Islamic religious learning activities at the Maung Bodas foundation is about necessary Islamic materials that are useful in daily life, especially in the context of improving one's religious behaviour, one of which is worship. The material taught at this foundation, for example, is the science of reading and writing of the Qur'an, the science of jurisprudence, reading prayer, aqeedah morals, and so forth. Basic teachings about reading the Qur'an and the procedures for worship into something that must first be taught intensively, remembering because most of the former recidivists indeed from the past and even from birth had embraced Islam, but they were in their past lives in circumstances far from religious ritual activities such as rarely praying, some even leave prayer altogether and do not know how to read the Qur'an.

So by teaching him how to read the Qur'an and the procedures for worship, it is hoped that the former recidivist can carry out his religious life well by improving his religious behaviour and can behave more positively in his daily life. This is in line with the objectives of Islamic guidance and counselling stated by Ahmad Mubarok quoted by Abdul Basit who explained that in its history the practice of Islamic guidance and counselling is known as Hisbah, which has the meaning of telling people to carry out the good deeds he left behind and prevent them and forbid him from doing evil deeds that he often does and reconcile when there are people who are fighting each other. (Basit, 2017) 


\section{Guidance for Reading the Qur'an}

For former recidivists who have not been able to read the Qur'an at all, the foundation will teach it from the beginning, namely from beginning to introduce letters hijaiyah (Arabic letters) to former recidivists. Then for those who can already read hijaiyah letters, it will be followed by reading qiro'ati (one of the quick methods of reading the Qur'an).

The former recidivists were taught how to read the Qur'an by the Yayasan administrators, especially by the clerics who were active in giving teachings to them namely Wa Ano as the head of the foundation which often jumped indirectly guiding the former recidivists, then Ustad Ruhimat, Ustad Mumu and Ustad Ajat. Former recidivists are guided in learning to read the Qur'an by the Ustad until they can, by being guided one by one intensely and together with a relaxed but severe learning atmosphere so that the learning participants do not feel pressured in their learning process

\section{Learning Procedures for Worship}

In this case, the former recidivists are taught how to purify from small and large hadas, are taught how to perform ablution, how to take a large shower, how to pray obligatory and readings as well as other necessary fiqh materials that can help former recidivists in carrying out their daily worship. In providing an understanding of the ways of worship as above. The instructors will explain the material from basic fiqh books such as the book safinatunnajah, and when the material is explained, the guide or instructor will practice it directly in front of the congregation so that the congregation who is being given an explanation of the worship procedures will get an idea of what to do if will perform ablution, prayer and more. So that the guidance participants or former recidivists who take part in these activities will quickly understand and quickly understand about good and right practices of worship.

\section{Islamic Counselling}

Apart from the guidance of reading the Qur'an and the procedures for worship, at this foundation, also former recidivists are invited to consult about the problems being faced in their lives to the mentors. These activities can be said as counselling or assistance activities carried out through the interview process or talking face to face and in ways how to change the behaviour of someone carried out by an experienced or expert to a client or more who experience problems. Guidance It is intended to find solutions and resolve the problems faced by a client. This counselling activity is usually done after the learning or lecture activities are finished.

With this Islamic counselling activity, it is expected that people who are in the problem can get a solution to the problems he is facing, or for former recidivists to forget the dark past of his past not to become a burden and lack of confidence in life. So that, given advice, advice on kindness, the former recidivist can be calmer in dealing with life. 
Rahman Abdullah: Model of Islamic Guidance and Counseling in Developing Religious Behavior and Interest of Leading Islamic Religious Former Recidivist in Padepokan Maung Bodas Ciamis Foundation

Table. 2. Schedule of Former Recidivist Guidance Activities at the Maung Bodas Foundation

\begin{tabular}{ccl}
\hline Hari & \multicolumn{1}{c}{ Waktu } & \multicolumn{1}{c}{ Kegiatan } \\
\hline Malam Selasa & $20.00-$ selesai WIB & Tadarus Al-qur'an dan doa bersama. \\
Malam Jum'at & $16.00-17.30$ WIB & $\begin{array}{l}\text { Belajar baca tulis Al-qur'an, terbuka unttuk } \\
\text { umum diutamakan bagi yang belum bisa } \\
\text { membaca Al-qur'an. }\end{array}$ \\
$\begin{array}{ll}\text { Persiapan buka puasa sunnah bersama. Dan } \\
\text { sholat maghrib berjamaah. }\end{array}$ \\
$\begin{array}{ll}\text { Tawasulan dan yasinan. } \\
\text { 20.00 WIB }\end{array}$ & $\begin{array}{l}\text { Istirahat dan evaluasi. } \\
\text { Kegiatan belajar mengajar materi sesuai yang } \\
\text { dibutuhkan dengan dilakukan dengan dibagi- } \\
\text { bagi dalam kelas dan di bimbing oleh pengajar } \\
\end{array}$ \\
& masing-masing. \\
& Latihan bela diri dan ilmu kanuragan \\
\hline
\end{tabular}

Activities undertaken at the Maung Bodas foundation such as the above schedule are usually followed by mentoring students who are from former recidivists and the general public. The Friday evening riyadoh was usually attended by more than 50 participants from ex-criminals or former thugs and the community around padepokan who wanted to study religious knowledge and participated in prayer \& dhikr activities at the Padepokan Maung Bodas Ciamis foundation.

The activities carried out at the Maung Bodas foundation, according to researchers, have used the principles of Islamic Guidance and Counselling in fostering former criminals to emigrate and improve their behaviour, especially their religious behaviour and to increase their interest in studying religious teachings as a guide in daily life.

We know that the basic principles of Islamic guidance and counselling are closely related to the aims and objectives of the Islamic counselling guide. Therefore this guidance is intended for someone or more in order to get peace and happiness in life in the world and in the hereafter, which is undoubtedly in line with Islamic teachings. The content of the material from the Islamic counselling guidance must be based on the teachings of Islam, and the guidance process is based on the relationship between humans who are based on Islamic teachings or ukhuwah Islamiah. One of the purposes and uses is to provide an understanding and perspective on the possibility of changing attitudes and behaviour of someone who is guided through Islamic guidance and counselling in their more religious lives in their daily lives. (Munadi Ardi, 2013)

Therefore, the activities carried out by the Padepokan Maung Bodas foundation intend to guide former recidivists to be steadfast in their hijrah and repent sincerely and be able to leave behind all the adverse actions that they often used to do. Then in the realm of Islamic counselling seen when the former recidivist asked for advice and advice from advisers to stay on the path of goodness and ask for motivation to always be enthusiastic in welcoming a better life. 
With the guidance from the management of the foundation for the former recidivists, which is carried out with an Islamic teaching approach, automatically the interest of the ex-recidivists to learn about Islam will increase and with the desire to study the religion is expected to have implications for religious behaviour and the life behaviour of the former recidivists is for the better.

\section{H. Religious Behaviour and Interest in Studying Islamic Religion Former Recidivist After Getting Islamic Guidance and Counselling at the Padepokan Maung Bodas Ciamis Foundation}

Changing something that has been done often or has become a habit that can be reflected in a person's behaviour is not easy. A recidivist who is used to living in criminal behaviour and often can be a threat to the lives and material of others, so that the community's stamp of criminals or recidivists will always be negative.

Negative views of these criminals will often be fixed by the community to someone who in the past was once a criminal and has now become aware and repentant, and has returned to the path of truth. So it is not uncommon for former criminals or ex-recidivists to be underestimated in life in social life. Therefore, with such a presumption in society towards former recidivists, the former criminals often feel inferior and insecure in carrying out their lives.

For this reason, the role of the Padepokan Maung Bodas Foundation in providing guidance, motivation and enthusiasm to former recidivists is significant and very helpful in strengthening the determination of former criminals to return to life in the right path. Padepokan Maung Bodas guided former recidivists to return to positive behaviour, especially to revive religious behaviour in ex-recidivists who in the past were far from worship and far from obedience in carrying out Islamic teachings.

\section{Former Recidivist Religious Behaviour After Getting Islamic Guidance and Counselling}

In knowing the results of this guidance on the religious behaviour of former recidivists in Maung Bodas, the researcher conducted interviews with former recidivists who were willing to be interviewed and shared their life stories. In addition to interviews, researchers also observed former recidivists who attended religious studies at the Maung Bodas foundation and participated in prayer and dhikr activities together at the foundation.

Of the many former recidivists who have followed the guidance and who routinely attend weekly activities at the Maung Bodas foundation, the researchers chose several ex-recidivists who would be examined for their religious behaviour when after getting guidance at the Maung Bodas foundation. Namely, the first initials EJ and the second IS, both are people who in the past were languished in bars because of the crimes they committed, and now they have repented and try to live better. 
First, the researcher successfully interviewed a male EJ who was one of the mentoring participants who came from a former recidivist who came from Situmandala Village, Rancah District. EJ, who now works as a mechanic, said that he is a former recidivist who often goes in and out of prison, he said he had been sent to prison six times, with different cases, such as robbery, stabbing, and the most serious was murder. After frequently committing crimes, in the end, he felt that what he was doing was wrong, so he began to realize and want to repent and want to return to a good life. Therefore, he looked for a place to study religion and looked for a figure who could be used as a guide in his efforts to emigrate. And then he got information that there was a hermitage in the Rancah-Ciamis area that housed former criminals or former thugs who wanted to be fostered and mentored.

EJ said that the beginning of his desire to repent is from within himself because indeed, everything that starts from the awareness within oneself will be easy to do anything in the future. EJ has joined Padepokan Maung Bodas for three years, and he said he had learned many lessons and had many changes in him, which had not been kind to be good.

Then the researcher alludes to the practice of religious rituals when he was still a criminal, meaning before getting guidance at Padepokan Maung Bodas and his religious behaviour after getting guidance at Padeopkan Maung Bodas. He explained the changes that occurred in him after attending the guidance activities at the Maung Bodas foundation, especially in matters of worship that had been when he was in the criminal world he had never carried out the prayer service. However, when repenting and getting Islamic guidance at the Maung Bodas foundation, he found a change in him who felt calmer life and began to perform the prayer again which he did not do at all, even though he admitted he still could not perform one hundred per cent of the obligatory prayers. Not only praying, the other worship he has begun to carry out such as fasting in the month of Ramadan and other worship, such as prayer and dhikr.

Second, the researcher also conducted interviews with other sources or other former recidivists of a man, IS. IS has a background not much different from EJ's first speaker, as a former recidivist murder case. IS is a participant of recidivist manatan guidance at the Maung Bodas foundation from Cidolog district, Ciamis district, who currently works as a driver. Before being guided at Maung Bodas, he got into trouble and suffered a prison sentence for murder. After leaving prison, he felt he wanted to change and finally met with Wa Ano as chairman of the Maung Bodas foundation. His meeting with Wa Ano made him determined to improve himself and behave positively. Like the former recidivist, IS has also joined the Maung Bodas foundation for three years.

IS who previously was a former criminal after following the guidance at the Maung Bodas foundation has begun to have awareness about religious behaviour, he said after getting guidance at this foundation in terms of worship there was an increase, and even he was able to become a mosque imam in leading five daily prayers in his village. Thus, the guidance activity has succeeded in growing religious behaviour towards someone 
who is guided to behave following religious guidelines and believe in the existence of God, who is almighty of all. (Marliany, 2010)

With already beginning to see the results of Islamic guidance and counselling conducted by the Padepokan Maung Bodas foundation for former criminals or exrecidivists who want to repent and want to return to the right path. By doing physical and spiritual guidance, especially guidance in performing compulsory worship in daily life.

With the guidance of the former criminal in Maung Bodas this had fostered the religious behaviour of former recidivists who were known when they were still in the criminal world, they rarely or even did not perform worship such as compulsory prayer. After they repent and there is awareness in themselves that life must go on and of course it must change for the better then gradually the religious behaviour grows in the former recidivists. The presence of feelings to keep themselves in the shade of goodness by carrying out worship in a way istiqomah or continuously and seriously.

2. Interest in Studying Islamic Religion Former Recidivist at the Maung Bodas Ciamis Foundation

The Padepokan Maung Bodas Foundation, which guides former recidivists, of course also provides character building and worship to the former recidivist by providing basic Islamic lessons, namely lessons on worship procedures and procedures for reading the Qur'an. From observations and interviews in the field, the researchers saw the enthusiasm of the participants of Islamic religious learning activities at the foundation, especially former recidivists who did not feel ashamed to study religion that might be commonly taught to young children such as learning to recognize hijaiyah letters and learning qiro'ati. For those who can read the Koran a little, they will be guided so that they can read it fluently.

The interest in studying religion from former recidivists is a consequence of the desire to improve themselves that arise from within the former recidivists themselves. Because learning can be interpreted as a change in behaviour or behaviour in a better direction or vice versa through a process of practice and experience. Learning is a change that occurs in a person who states themselves as a pattern, a new understanding of attitudes, skills, and habits. (Purwanto, 2013)

With the existence of self-awareness is the initial capital for former criminals to step in a better life and benefit the environment. The Maung Bodas Foundation has taken an essential step in guiding and nurturing people who have a dark background in their past to be repaired and directed to live in the shade of peaceful and benevolent Islamic teachings. The emergence of interest in studying Islam from former recidivists at the Maung Bodas foundation is a follow-up to the awareness and desire to emigrate from former recidivists. When someone wants to get closer to God and wants to increase the intensity of his observance in religion, then that person will automatically be active in studying and deepening his religious understanding to support the implementation of 
religious rituals or worship that is good and right and certainly following the guidance of religion itself.

\section{Conclusion}

Guidance activities for former recidivists at the Maung Bodas foundation are carried out in Islamic ways, namely by way of ruqiyah syar'iyyah, then prayer and dzikir therapy as well as calm in a person who wants to be guided at the foundation. The guidance activity is carried out by applying guidance patients if they feel more intensive guidance is needed, then by following the routine activities held by the foundation on Tuesday and Friday nights. The guidance activity is intended to provide an understanding of the teachings of Islam and guide the former recidivist to increase his worship of Allah SWT. Activities carried out routinely at the foundation contain religious themes by providing teachings on the teachings of Islam that can support the occurrence of religious behaviour from the former recidivists.

With the guidance based on Islamic teachings to former recidivists at the Maung Bodas Foundation, it has an impact on the guidance participants, especially ex-recidivists who have found changes in themselves and their behaviour and lives that were filled with negative things are now filled with things positive. Then in terms of religious behaviour and interest in learning about Islam and religion increased. It was proven by the existence of a former recidivist who had re-introduced worship such as prayer which he had often left behind. After following the guidance at the Maung Bodas foundation, he began to pray again and even some who could already become imams in prayer.

In principle, Padepokan Maung Bodas has carried out Islamic guidance and counselling activities in fostering and guiding people who are often underestimated by the community or may even be considered as common trash to improve their life behaviour towards a better direction and can return to human nature, namely someone who has a noble character and is obedient to the teachings of Islam. Islamic guidance and counselling activities carried out by the Padepokan Maung Bodas Foundation for exactivists have opened our horizons not to underestimate other people, even though that person has a dark background, because when God's guidance comes and Allah SWT is pleased to re-elevate people that person will be glorious before Allah SWT because the most noble people in the sight of God are those who draw closer to Allah and devote themselves to Him.

\section{References}

Abdullab, S. (2007). Islam and Counseling: Models of Practice in Muslim Communal Life. Journal of Pastoral Counseling, 42.

Amiruddin, A., Askar, A., \& Yusra, Y. (2019). Development of Islamic Religious Education Learning Model based on Multicultural Values. International Journal of Contemporary Islamic Education, 1(1), 1-19.

Asmani, J. M. M. (2010). Panduan Efektif Bimbingan dan Konseling di Sekolah. Jogjakarta: 
Diva Press, Jamal Ma'mur.

Basit, H. A., \& Ag, M. (2017). Konseling Islam. Prenada Media.

Dewi, E. W., Nurkamto, J., \& Drajati, N. A. (2019). Exploring Peer-Assessment Practice in Graduate Students'academic Writing. LLT Journal: A Journal on Language and Language Teaching, 22(1), 58-65.

Fattah, N. (2019). Landasan manajemen pendidikan.

Habibi, H. (2018). Protecting National Identity Based On The Value Of Nation Local Wisdom. International Journal of Malay-Nusantara Studies, 1(2), 24-40.

Habibi, H. (2016). Peran Ki Dalang Basari (1950-2003) dalam Perkembangan Islam di Gegesik Cirebon. Jurnal Tamaddun: Jurnal Sejarah dan Kebudayaan Islam, 1(2).

Hartono, M. S. (2015). Psikologi Konseling. Kencana.

Haque, A., Khan, F., Keshavarzi, H., \& Rothman, A. E. (2016). Integrating Islamic traditions in modern psychology: Research trends in last ten years. Journal of Muslim Mental Health, 10(1).

Hasanah, A., Gustini, N., \& Rohaniawati, D. (2016). Nilai-Nilai Karakter Sunda. Deepublish. Kartika, W. (2019). Bimbingan Karier Terhadap Santri Salafi"(Studi di Pondok Pesantren.

Darussibyan Kecamatan Cadasari Kabupaten Pandeglang) (Doctoral dissertation, Universitas Islam Negeri Serang Banten).

Listiyani, N., Wibowo, M. E., \& Sutoyo, A. (2019). Guidance Group Based on Islamic Teachings with Simulation Game Techniques to Improve Interpersonal Communication. Jurnal Bimbingan Konseling, 8(1), 59-66.

Manzilati, A. (2017). Metodologi Penelitian Kualitatif: Paradigma, Metode, dan Aplikasi.

Universitas Brawijaya Press.

Marliany, R. (2010). Psikologi umum. Bandung: Pustaka Setia, 3.

Mubarok, A. (2000). al Irsyad an nafsy: konseling agama teori dan kasus. Bina Rena Pariwara.

Nuroni, E., \& Khambali, K. (2016). Implementasi Pembentukan Karakter Khas Madrasah Pada Peserta Didik Di MI Asih Putera Kota Cimahi. Ta'dib: Jurnal Pendidikan Islam, 5(1), 61-70.

Purwanto, M. N. (2013). Psikologi Pendidikan, Cet. 26 Bandung: PT. Remaja Rosdakarya.

Ramayulis, H. (2019). Psikologi agama.

Rajab, K. (2012). Psikologi Agama.

Rassool, G. H. (2015). Islamic counselling: An introduction to theory and practice. Routledge.

Rehan, F., Block, J. H., \& Fisch, C. (2019). Entrepreneurship in Islamic communities: How do Islamic values and Islamic practices influence entrepreneurship intentions?. Journal of Enterprising Communities: People and Places in the Global Economy, Forthcoming.

Sa'adah, M. (2018). Peran Sanggar Suwanda group dalam melestarikan seni tradisonal Tari Jaipongan di Kabupaten Karawang (Bachelor's thesis, UIN Syarif Hidayatullah Jakarta: Fakultas Adab dan Humaniora, 2018).

Sudan, S. (2017). Principles of Islamic Counseling and Psychotherapy. Asian Journal of Management Sciences \& Education, 6(3), 129-138.

Sutoyo, A. (2013). Bimbingan dan Konseling Islami (teori dan praktik). Yogyakarta: Pustaka Pelajar. Zakaria, N., \& Akhir, N. S. M. (2019). Incorporating Islamic Creed into Islamic Counselling Process: A Guideline to Counsellors. Journal of religion and health, 58(3), 926-936.

Zamroni, E. (2016). Counseling Model Based on Gusjigang Culture: Conceptual Framework of Counseling Model Based on Local Wisdoms in Kudus. GUIDENA: Jurnal Ilmu Pendidikan, Psikologi, Bimbingan dan Konseling, 6(2), 116-125.

Cite: Abdullah, R. (2020). Model of Islamic Guidance and Counseling in Developing Religious Behavior and Interest of Leading Islamic Religious Former Recidivist in Padepokan Maung Bodas Ciamis Foundation. Diadikasia Journal, 1(1), 24-38. https://doi.org/10.21428/8c841009.1aba57e2 